\title{
Occurrence of metastable rocks in deeply subducted continental crust from the Dabie Mountains, central China
}

\author{
1. Institute of Geomechanics, CAGS, Beijing, 100081, China \\ 2. Institut für Geowissenschaften, Universität Potsdam, Potsdam, D-14415, Germany \\ 3. Geological Survey of Anhui, Hefei, 230001, China
}

A recent study reveals that metamorphic volcanic and sedimentary rocks have survived deep subduction of continental crust in the Dabie Mountains, central China. These low-grade $(L G)$ rocks are intercalated within the ultrahigh-pressure (UHP) metamorphic terrane and well preserve primary volcanic breccia structure and sedimentary bedding. The presence of coherent field relations between $L G$ and UHP rocks suggests that $L G$ rocks are not of exotic origin and therefore suffered from UHP metamorphism. They, however, did not record the UHP event likely due to slow reaction kinetics, and only experienced epidote-amphibolite to greenschist facies metamorphism and deformation at the retrograde stage of UHP rocks. The protolith age of c. 790 $\mathrm{Ma}$ and metamorphic age of $232.2 \mathrm{Ma}$ obtained from $L G$ rocks, which agree well with those from UHP rocks, also suggest that both $L G$ and UHP rocks shared the same evolutionary history since Late-Proterozoic. Except for the lack of deformation and fluid during UHP metamorphism, the rapid subduction, short stay at mantle depths and rapid exhumation are necessary for the preservation of primary assemblage and fabric in $L G$ rocks within deeply subducted continental crust.

\section{Introduction}

Due to the discovery of coesite in diverse metamorphic rocks, including eclogite, metapelite, marble, jadeite quartzite and gneiss (Xu, 1987; Okay et al., 1989; Wang et al., 1989; Wang and Liou, 1991, 1993; Su et al, 1996; Tabata et al, 1998), the Dabie Mountains in central China have been considered to be a slab of deeply subducted continental crust. Most geologists assumed that the coesitebearing rocks together with their country rocks in the slab underwent in situ UHP metamorphism (e.g. Wang and Liou, 1991; Okay, 1993; Liou et al., 1996; Xue et al., 1996; Rowley et al., 1997; Carswell et al., 2000). However, on the basis of detailed geological research on the field relations, some geologists, especially Chinese investigators, only accepted that the rocks associated closely with eclogite had experienced UHP metamorphism, but argued that the widespread granitic gneisses were of lower metamorphic grade (LG), and were juxtaposed with UHP rocks at crustal level (e.g. Zhai et al., 1995;
Cong et al., 1995, 1999; Liu et al., 1999). In fact, both considerations are problematic because of the lack of index textural and mineralogical evidence.

Are there any non-UHP rocks in the deeply subducted continental crust of the Dabie Mountains? If yes, what are the real relations between them and UHP rocks? A detailed field geological study revealed some LG volcanic and sedimentary rocks in Ganghe (Tang et al., 1995; Dong et al., 1997), and further large scale geological mapping proved that there are many LG rock blocks within the UHP terrane. It is very interesting that a coesite-bearing eclogite was recently found intercalated in the LG volcanic rocks, which led Gao et al. (1997) to propose a magmatic origin of UHP eclogite. This paper summarizes new petrological, structural and geochronological data and gives an interpretation about the origin of LG rocks and its relations to UHP rocks.

\section{Regional geology and field relations}

The regional geology of the Dabie Mountains in central China has been described by many geologists (e. g. Dong et al., 1993; Liou et al., 1996; Cong et al., 1996). A large scale (1:50,000) geological mapping by the Anhui Bureau of Geology and Mineral Resources (1996, unpubl.) revealed that the Dabie Mountains UHP terrane comprised two major lithological units, the granitic gneiss unit and the UHP unit (cf. Liu et al., 1999). Recently, based on the 1:10,000 geological mapping in Changpu area (Anhui Bureau of Geology and Mineral Resources, 2000), Schmid et al. (2000) distinguished for the first time basement-cover sequences in the UHP unit (Figure 1A). The basement is composed of quartzo-feldspatic orthogneiss with some eclogite lenses or blocks. The cover can be divided into the Changpu unit and the Ganghe unit. The former consists of garnetbiotite-plagioclase gneiss, garnet-phengite schist, garnet-jadeite quartzite, and marble with numerous eclogite pods or lenses. The later is chiefly constituted by metavolcanic rocks with minor metasedimentary rocks and eclogites (Dong et al., 1997, Schmid, 2001; Schmid et al., 2001). The reconstruction of the pre-UHP stratigraphy of the cover is shown in Figure 1B.

The LG volcanic and sedimentary rocks occur in the Ganghe unit, about $4 \mathrm{~km}$ south of Changpu. 11 LG blocks on different scales have been distinguished within $3.5 \mathrm{~km}^{2}$ area (Figure 1A). LG rocks consist of laminated metapelitic sandstone, metatuff breccia and phengite-albite-quartz schist. Primary sedimentary structures, such as graded, rhythmic and inclined bedding, and slumping and channel structures, are well preserved in the sedimentary rocks (Figure 2a). Breccia clasts and primary igneous plagioclase crystals are preserved in the volcanic rocks (Figure $2 b$ ). Although LG rocks are discontinuously distributed, the regular arrangement from phengitealbite-quartz schist through metatuff breccia to metapelitic sand- 

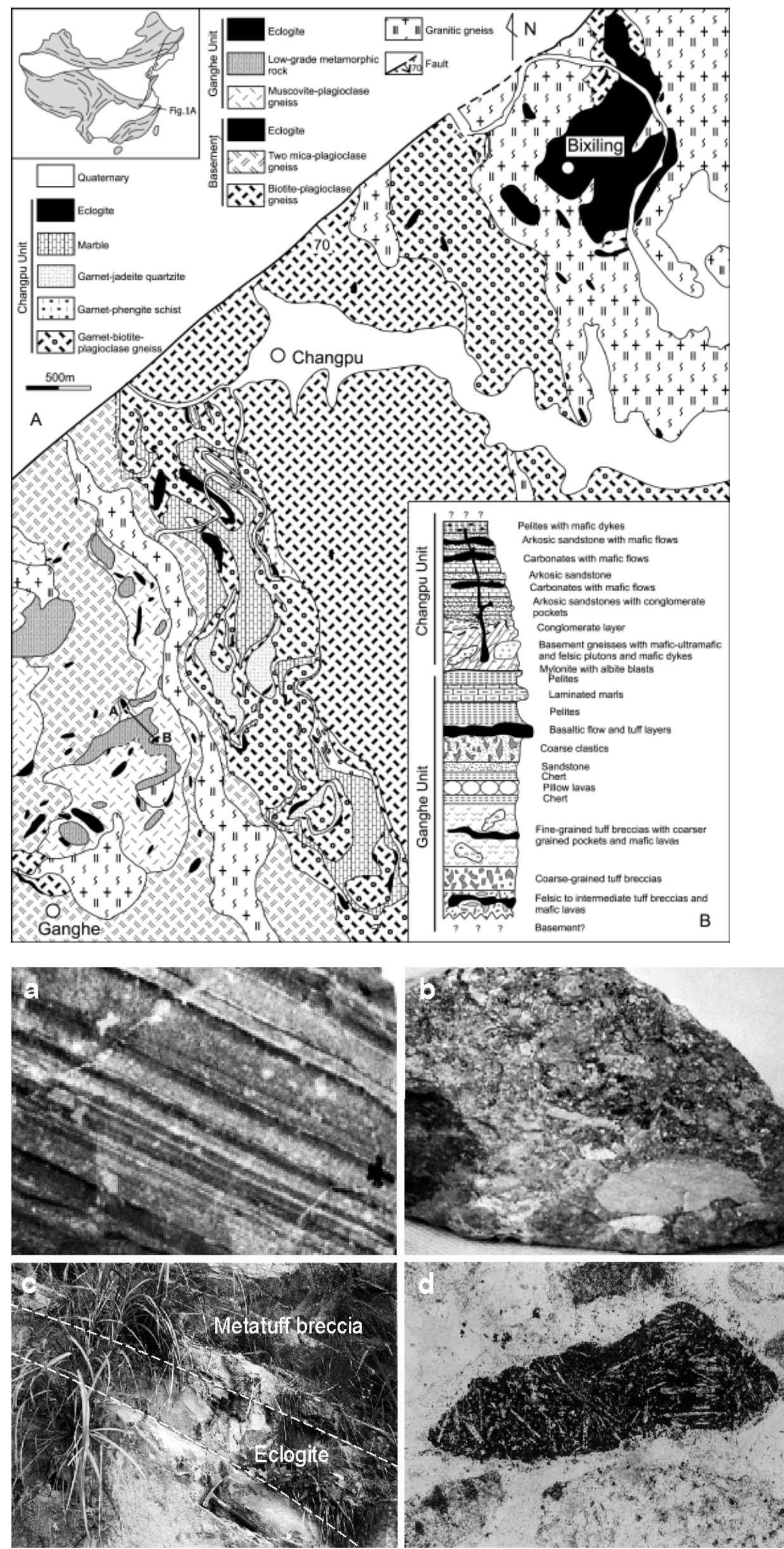

Figure 1 Geological map of GangheChangpu area, southeastern Dabie Mountains (A) and its location in China (after Anhui Bureau of Geology and Mineral Resources, 2000, and Schmid, 2001). B shows the reconstruction of the pre-UHP stratigraphy of the cover. $A-B$ shows the location of Figure 3.

Figure 2 (a) Photograph showing rhythmic bedding in metasedimentary rock. Width of view is $8 \mathrm{~cm}$.

(b) Photograph showing rhyolitic clasts in metatuff breccia. Width of view is $12 \mathrm{~cm}$.

(c) Photographs showing an eclogite intercalated within metatuff breccia.

(d) Photomicrograph showing an igneous lithoclast with intergranular texture composed of albite, Ti-bearing hematite and minor biotite and apatite in metasedimentary rock. Width of view is $0.5 \mathrm{~cm}$. 
stone implies that they may be a continuous volcanic-sedimentary sequence.

The lithological and structural section of a typical LG volcanic rock block near Ganghe Bridge is illustrated in Figure 3. There are two metatuff breccia layers about $30 \mathrm{~m}$ and $5 \mathrm{~m}$ thick. The main components of breccia are rhyolites, with clast content of 10-30 vol.\% and grain size ranging from $1 \mathrm{~cm}$ to $5 \mathrm{~cm}$. An eclogite $40 \mathrm{~cm}$ wide is intercalated in the metatuff breccia (Figure 2c), which may represent an earlier mafic dyke. Three phengite-albite-quartz schist layers occur beside the metatuff breccia. Their protolith may be tuff lava. The country rocks of LG block are mica gneisses with abundant coesite-bearing eclogite bands or lenses. The typical mineral assemblage in such eclogites is garnet + omphacite + phengite + zoisite + quartz/coesite + rutile \pm kyanite. Except for the increasing intensity of foliation, no clear tectonic boundary has been found between LG and UHP rocks.

\section{Deformation, petrology and geochronology}

\section{Deformation}

Most metapelitic sandstones have not recorded deformational episodes, but sericite in a few samples exhibits a weak orientation parallel to the bedding. Phengite in metatuff breccia is strongly oriented and forms the penetrative $S_{1}$ foliation. It can be seen that phengite often grew around the stretched breccia, and that plagioclase phenocrysts were rotated. Both elongation lineations $\left(\mathrm{L}_{1}\right)$ of breccia and metamorphic minerals strike NW-SE ( $\left.S_{1} 140 / 40, L_{1} 170 / 40\right)$, in agreement with the A-type lineation in UHP rocks (Figure 3). The inner part of the eclogite does not exhibit any deformation except later schistosity defined by retrograde minerals developed in its margin. The preferred orientation of phengite in phengite-albite-quartz schist constitutes strong foliation. A small-scale A-type fold developed in the rocks. Two stages of deformation can be recognized near

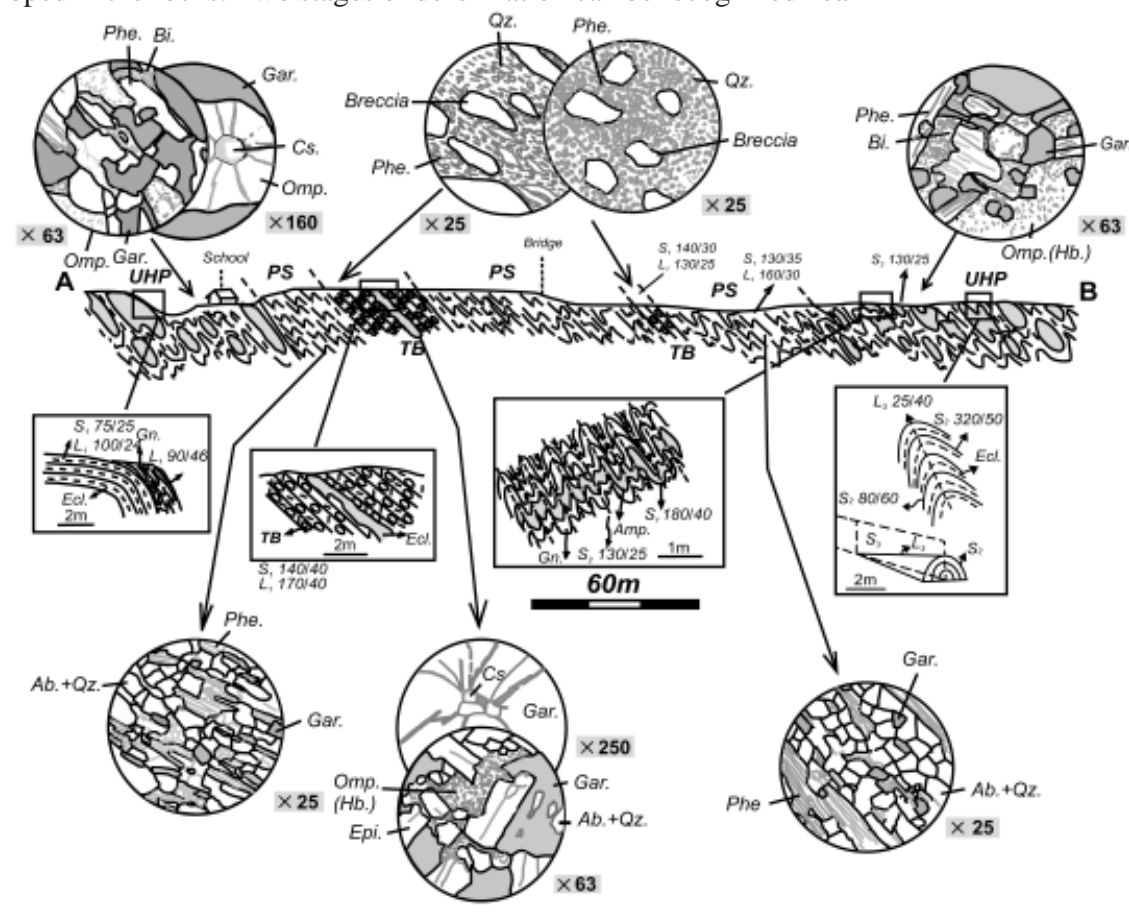

Figure 3 Lithological and structural section of a low-grade metamorphic volcanic rock block in the UHP unit near Ganghe Bridge. UHP-ultrahigh-pressure metamorphic rocks; PS-phengite-albite-quartz schist; TB-metatuff breccia. Amp.—amphibolite; Ecl.—eclogite; Gn._gneiss. Ab.-albite; Bi._biotite; Cs._coesite; Epi._epidote; Gar.—garnet; Hb.—hornblende; Omp.-omphacite; Phe.-Phengite; Qz.-quartz.
UHP rocks, and its principal foliation $\left(\mathrm{S}_{1}\right)$ corresponds to the second deformation $\left(\mathrm{D}_{2}\right)$ in eclogites (Figure 3 ).

Similar to the descriptions by Xue et al. (1996) in Shima area, three major generations of deformation are also recognized in the UHP rocks in Ganghe. The $\mathrm{D}_{1}$ deformation, usually forming the $\mathrm{S}_{1}$ foliation (180/40) and $\mathrm{L}_{1}$ lineation, consists of banded compositional layer in eclogites, which represents the earlier deformation formed under UHP conditions during subduction. The $\mathrm{D}_{2}$ was deformed by the compositional layer and $S_{1}$ foliation, and A-type fold with the $S_{2}$ axial-planar foliation (130/25) and $\mathrm{L}_{2}$ lineation occurred. The compositional layer $\left(\mathrm{S}_{1}\right)$ in the country gneisses of eclogite was entirely replaced by the $S_{2}$ foliation. $D_{2}$ is a major deformation event in the Dabie Mountains UHP terrane and represents the plastic deformation formed under amphibolite facies during early exhumation of UHP rocks. The $\mathrm{D}_{3}$ deformation is characterized by open, NEplunging folds ( $\mathrm{L}_{3}$ 25/40) with nearly vertical axial plane, which records the deformation formed at a shallow level during late exhumation of UHP rocks.

\section{Petrology}

Metapelitic sandstone is composed of porphyroclasts and detrital matrix. The compositions of porphyroclasts are quartz, feldspar and minor amounts of igneous lithoclasts. They are circular, rectangular or angular with an average grain size of $0.05-0.5 \mathrm{~mm}$, but sometimes gravels as large as $1-2 \mathrm{~mm}$ occur. Igneous lithoclasts usually preserved intergranular texture composed of albite $(\mathrm{An}=7)$, Ti-bearing hematite and minor biotite and apatite (Figure 2d). All quartz porphyroclasts have recrystallized to polycrystalline aggregates. Matrix comprises sericite, chlorite, felsic minerals and sometimes a few epidote and biotite crystallites, with an average grain size of $<1 \mu \mathrm{m}$. This mineral assemblage suggests a metamorphic grade of lower greenschist facies.

Metatuff breccia consists of phengite, epidote, feldspar, quartz and a small amount of biotite, sphene and garnet. They crystallized relatively bigger grains as compared with metapelitic sandstone, with an average grain size ranging from 0.01 to $0.02 \mathrm{~mm}$. Garnet is
rich in Mn with spessartine content of $25-30 \mathrm{~mol} . \%$. Phengite is rich in $\mathrm{Fe}$, with $\mathrm{Si}$ values of 3.24-3.39 p.f.u. and $\mathrm{Mg} / \mathrm{Mg}+\mathrm{Fe}^{2+}$ ratio of $0.31-0.39$. The metamorphic conditions are difficult to estimate due to the lack of diagnostic mineral assemblages. Phengite barometer calibrated by Massonne and Schreyer (1987) yields a pressure of 6-10 $\mathrm{kbar}$ (assumed $\mathrm{T}=$ $500^{\circ} \mathrm{C}$ ), but this pressure estimates are only minimum values due to the absence of K-feldspar. The absence of jadeite in presence of albite in the rock limits the pressures to less than 13-14 kbar. The temperature of $460-490^{\circ} \mathrm{C}$ was obtained based on garnet-muscovite geothermometer (Hynes and Forest, 1988) (assumed $\mathrm{P}=8 \mathrm{kbar}$ ).

Phengite-albite-quartz schist is mediumgrained with an average grain size of $0.05-0.1 \mathrm{~mm}$. The constituent minerals are phengite, epidote, albite, quartz and minor amounts of biotite and garnet. Garnet is also Mn-rich with spessartine content of 29-46 mol.\%. Phengite reveals Si values of $3.24-3.39$, but $\mathrm{Mg} / \mathrm{Mg}+\mathrm{Fe}^{2+}$ ratio is higher, ranging from 0.44 to 0.55 . The small grains of epidote are euhedral and homogeneous in composition, but a zoisite core often occurs in big crystals. The temperature calculated by garnet-muscovite geothermometer ranges from 490 to $510^{\circ} \mathrm{C}$ (assumed $\mathrm{P}=8 \mathrm{kbar}$ ), in accordance with epidoteamphibolite facies conditions.

The above shows that the mineral assemblage, chemistry and P-T conditions of LG rocks correspond systematically to those of retrograde eclogites and their country rocks (Liou et al., 1996). These identical P-T estimates as well as the 
field relations and the textures described in this paper and by Schmid (2001) demonstrate that coherent basement-cover series are present and survived the ultrahigh-pressure metamorphism.

Eclogite intercalated in metatuff breccia comprises fine-grained garnet, omphacite, epidote, quartz and rutile. Coesite occurs as inclusions in garnet and quartz pseudomorph after coesite in both garnet and epidote. The presence of glomeroblastic epidote and quartz, and epidote content up to $30 \mathrm{vol} . \%$ indicate that fluid plays an important role during eclogite formation. The metamorphic temperature calculated by garnet-clinopyroxene geothermometer (Krogh, 2000) ranges from 710 to $780^{\circ} \mathrm{C}$ (assumed $\mathrm{P}=40 \mathrm{kbar}$ ), similar to that of coesite-bearing eclogite $\left(750 \pm 50^{\circ} \mathrm{C},>30 \mathrm{kbar}\right)$ occurring in the UHP unit. This implies that the eclogite was not of magmatic origin, as Gao et al. (1997) suggested. The margin of eclogite has transformed into more fine-grained symplectite of epidote-amphibolite facies.

\section{Geochronology}

The age of LG rocks was determined by various dating techniques including the stepwise thermal evaporation-deposition technique for single zircon grains and the whole-rock Sm$\mathrm{Nd}$ and $\mathrm{Rb}-\mathrm{Sr}$ isochrons in the Laboratory of Isotope Geochronology at the Chinese Academy of Geological Sciences. Analytical procedures and methods have been illustrated by $\mathrm{Li}$ et al. (1993) and Zhao et al. (1995). As a result, the ${ }^{207} \mathrm{~Pb} / 206 \mathrm{~Pb}$ ages of four zircons separated from a phengite-albite-quartz schist are 760 $\pm 9,769 \pm 7,745 \pm 6$ and $802 \pm 3 \mathrm{Ma}$, respectively (Table 1). The whole-rock Sm-Nd isochronic age for seven samples of such rock is $790.9 \pm$ 18.6 Ma (Table 2, Figure 4a). The coincidence between Pb$\mathrm{Pb}$ age and whole-rock Sm-Nd age indicates that the protolith age of LG rocks is c. $790 \mathrm{Ma}$, which is not only in accordance with the protolith age of eclogites in the UHP unit (Ames et al., 1996), but also in accordance with that of granitic gneisses (Rowley et al., 1997; Hacker et al., 1998, 2000). The whole-rock Rb-Sr isochronic age of $232.2 \pm 8.2$ Ma was obtained with the same 7 samples (Table 3, Figure $4 \mathrm{~b}$ ). It is equivalent to the generally recognized metamorphic age of eclogites in the UHP unit in the Dabie Mountains, c. 220-240 Ma

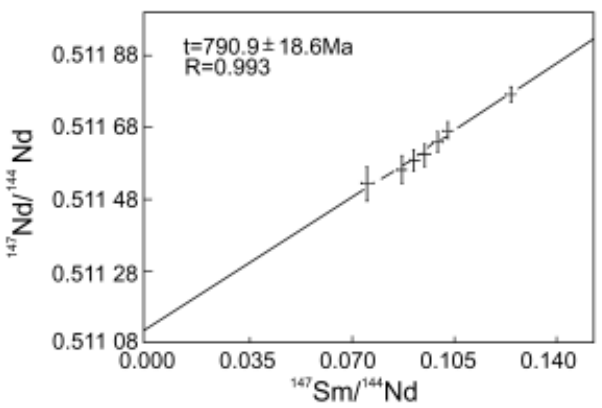

Figure 4 The whole-rock $\mathrm{Sm}-\mathrm{Nd}(\mathrm{A})$ and $\mathrm{Rb}-\mathrm{S}$ metamorphic rocks in Ganghe.

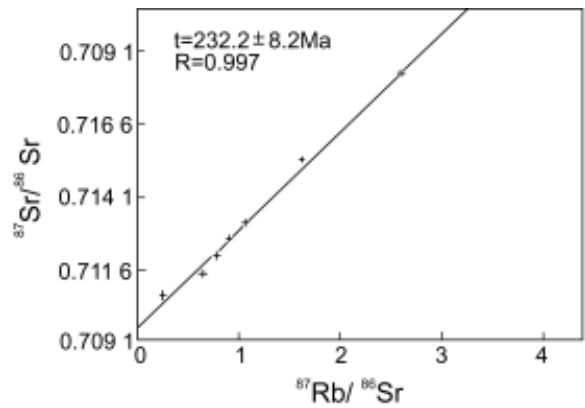

(B) isochronic ages for low-grade

Table $1 \mathrm{~Pb} / \mathrm{Pb}$ isotopic ratios released from single zircon stepwise evaporation of a phengite-albite-quartz schist from Ganghe.

\begin{tabular}{|c|c|c|c|c|c|c|c|c|c|c|c|c|c|}
\hline \multirow[b]{2}{*}{ No. } & \multirow[b]{2}{*}{ Order } & \multirow[b]{2}{*}{ Group } & \multicolumn{5}{|c|}{ Isotope of zircon } & \multicolumn{5}{|c|}{ Result } & \multirow[b]{2}{*}{ Description of zircon } \\
\hline & & & $208 / 206$ & $2 \sigma$ & $207 / 206$ & $2 \sigma$ & $204 / 206$ & $2 \sigma$ & $207 / 206$ & $2 \sigma$ & $\begin{array}{l}\text { ages } \\
\text { Ma }\end{array}$ & $\begin{array}{l}2 \sigma \\
M a\end{array}$ & \\
\hline 1 & 2 & 5 & 0.4819 & 27 & 0.07082 & 36 & 0.000343 & 33 & 0.06454 & 29 & 760 & 9 & $\begin{array}{l}\text { Colorless, relatively transparent, } 380 \mu \mathrm{m} \times 90 \mu \mathrm{m} \times \\
1170 \mu \mathrm{m} \times 80 \mu \mathrm{m} \times 1 \text {, (110) (111) faces, less } \\
\text { fissure, no corrosion } \\
220 \mu \mathrm{m} \times 150 \mu \mathrm{m} \times 1 \text {. (110) (111) (311) faces, }\end{array}$ \\
\hline 2 & 1 & 10 & 0.4523 & 32 & 0.07543 & 48 & 0.000734 & 38 & 0.06482 & 22 & 769 & 7 & $\begin{array}{l}\text { complex crystal faces } \\
200 \mu \mathrm{m} \times 120 \mu \mathrm{m} \times 4,(110)(111) \text { faces, simple }\end{array}$ \\
\hline 3 & 1 & 4 & 0.6155 & 62 & 0.0794 & 10 & 0.00011 & 7 & 0.06409 & 18 & 745 & 6 & crystal faces \\
\hline 5 & 1 & 8 & 0.3782 & 9 & 0.07478 & 17 & 0.000632 & 12 & 0.06566 & 11 & & & $170 \mu \mathrm{m} \times 80 \mu \mathrm{m} \times 4$ \\
\hline & 2 & 5 & 0.04837 & $\begin{array}{l}18 \\
\mathbf{I}_{1}\end{array}$ & $\begin{aligned} 0.07307 \\
-I_{2}=13 \text { bloc }\end{aligned}$ & 18 & 0.000475 & 23 & $\begin{array}{l}0.06619 \\
0.06586\end{array}$ & $\begin{array}{l}12 \\
11\end{array}$ & 802 & 3 & \\
\hline
\end{tabular}

Parameter used: $\lambda_{238}=1.5513 \times 10^{-10}, \lambda_{235}=9.8485 \times 10^{-10},{ }^{238} \mathrm{U} / 235 \mathrm{U}=137.88 ;$ No. $=$ zircon crystal numbers; order $=$ depositional order; groups $=$ data groups measured after a deposition (block number); cach block consists of 8 times of scanning; $207 / 206$ in the result column refers to radiogenetic $\mathrm{Pb}$ isotopic ratio; $\sigma$ value corresponds to the last two or one number of the ratio, e.g. $208 / 206=0.1732, \sigma=17$ for $208 / 206=0.1732 \pm 0.0017$.

Table 2 Sm-Nd isotopic compositions of Phengite-albite-quartz schist from Ganghe.

\begin{tabular}{cccccc}
\hline No. & $\mathbf{S m} / \mathbf{1 0}^{-\mathbf{6}}$ & $\mathbf{N d} / \mathbf{1 0}^{\mathbf{6}}$ & ${ }^{\mathbf{1 4 7}} \mathbf{S m} /{ }^{\mathbf{1 4 4}} \mathbf{N d}$ & ${ }^{\mathbf{1 4 3}} \mathbf{N d} /{ }^{\mathbf{1 4 4}} \mathbf{N d}$ & $\pm \mathbf{2} \sigma$ \\
\hline $94303-2$ & 3.643 & 29.28 & 0.07526 & 0.511521 & 24 \\
$94303-3$ & 4.298 & 29.83 & 0.08712 & 0.511563 & 20 \\
$94303-4$ & 4.372 & 28.92 & 0.09145 & 0.511587 & 22 \\
$94303-5$ & 8.998 & 57.38 & 0.09486 & 0.511601 & 16 \\
$94303-6$ & 9.043 & 55.01 & 0.09947 & 0.511637 & 15 \\
$94303-7$ & 8.987 & 52.76 & 0.10310 & 0.511668 & 10 \\
$94303-8$ & 11.48 & 55.36 & 0.12540 & 0.511770 & 12 \\
\hline
\end{tabular}

Table 3 Rb-Sr isotopic compositions of Phengite-albite-quartz schist from Ganghe.

\begin{tabular}{cccccc}
\hline No. & $\mathbf{R b} / \mathbf{1 0}^{-\mathbf{6}}$ & $\mathbf{S r} / \mathbf{1 0}^{-\mathbf{6}}$ & ${ }^{\mathbf{8} 7} \mathbf{R b} /{ }^{\mathbf{8 6}} \mathbf{S r}$ & ${ }^{87} \mathbf{S r} \mathbf{}^{\mathbf{8 6}} \mathbf{S r}$ & $\pm \mathbf{2} \boldsymbol{\sigma}$ \\
\hline $94303-2$ & 78.63 & 85.04 & 2.6350 & 0.718281 & 22 \\
$94303-3$ & 73.64 & 877.6 & 0.2391 & 0.701697 & 23 \\
$94303-4$ & 64.36 & 168.5 & 1.0884 & 0.713204 & 26 \\
$94303-5$ & 68.91 & 208.6 & 0.9247 & 0.712695 & 18 \\
$94303-6$ & 89.45 & 323.4 & 0.7882 & 0.712146 & 16 \\
$94303-7$ & 95.78 & 430.2 & 0.6344 & 0.711440 & 14 \\
$94303-8$ & 120.8 & 210.8 & 1.6382 & 0.715346 & 12 \\
\hline
\end{tabular}


(Li et al., 1993; Ames et al., 1996; Chavagnac and Jahn, 1996), representing the collision timing of the North China and Yangtze Cratons.

\section{Discussion and conclusions}

The preservation of primary sedimentary bedding and volcanic breccia suggests that LG rocks within Ganghe sequence have never transformed into UHP assemblage. The absence of sharp tectonic boundaries between LG and UHP rocks, however, precludes LG rocks from being exotic blocks. The protolith age of $c .790 \mathrm{Ma}$ and metamorphic age of 232.2 Ma obtained from LG rocks, which agrees well with those from UHP rocks, also suggest that LG rocks shared the same evolutionary history with UHP rocks. Accordingly, it is assumed that LG rocks occurring within the Dabie Mountains UHP terrane are the relics of the Yangtze continental crust. When the Yangtze slab subducted to mantle depth (more than $100 \mathrm{~km}$ ), the main part of the slab experienced intense plastic deformation and transformed into UHP assemblage, but in some places of the slab, composed of volcanic and sedimentary rocks, minerals did not transform because of slow reaction kinetics, and therefore preserved primary mineral assemblages. When they were uplifted to the crustal levels, they were subjected to epidote-amphibolite to greenschist facies metamorphism and deformation together with surrounding UHP rocks. The occurrence of undeformed fine-grained eclogite within metatuff breccia supports this hypothesis.

Metamorphic heterogeneity between LG and UHP rocks depends on the chemical compositions of protolith, deformation and fluid conditions. Mafic rocks in the subducted slab are easily transformed into eclogites as compared with intermediate-acid rocks. The most important example comes from a granitoid intrusion (granite and granodiorite) in Monte Mucrone, Sesia-Lanzo zone, Italy (Oberhänsli et al., 1985), where the mafic inclusions within granitoid have entirely been transformed into eclogites, whereas granitoid well preserved primary granitic fabric and assemblage. Only in high-strain zones or fluid-rich places, fine-grained garnet was formed along the rim of biotite, jadeite + zoisite + quartz after plagioclase, and phengite after K-feldspar. Therefore, whether or not granitoid transformed into high-pressure assemblage hinges on the behavior of deformation and the supply of fluid. The similar case has also been found in Kaghan Valley, N Pakistan (O'Brien and Treloar, 2001). Actually, gabbroic structure and mineral assemblage preserved within coesite-bearing eclogite have been found in Yangkou, the Sulu terrane (Zhang and Liou, 1997). The relict LG rocks in Ganghe of the Dabie Mountain seem to supply another example for the fact that primary low-pressure assemblage could be preserved within UHP metamorphic belt.

This study for LG rocks from Ganghe supplies new evidence to understand the protolith of UHP rocks, which have mostly been destroyed under UHP metamorphic condition, and a new clue to seek the basement of Yangtze craton. There is also an important implication to reconstruct the process of collision between North China and Yangtze craton. When discussing the mechanism of continent-continent collision producing UHP rocks, many geologists focused their attention on the exhumation of UHP rocks. They considered that coesite requires a rapid tectonic uplift, and a very short time (c. 10-20 Ma) for the exhumation of UHP rocks from mantle depth to crustal level has been suggested (Hacker et al., 1995, 1998; Maruyama et al., 1998; Webb et al., 1999). However, the subducting process seems to be difficult to infer because of the absence of geological information prior to UHP metamorphism. The presence of LG rocks in the UHP terrane gives us a chance to discuss this problem. Actually, although the lack of deformation and fluid plays an important role in the preservation of LG rocks, they would also be transformed to UHP assemblage when the slab slowly subducted leading to increasing geothermal gradient, or the subducted slab stayed at mantle depths for a long time. This suggests that UHP rocks underwent a rapid subduction and a short stay at mantle depths, implying that the subducted continental crust must be rapidly transformed into uplift after subduction. Thus, the tectonic model of rapid subduction accompanying closely rapid exhumation (Davy and Gillet, 1986; Platt, 1986; Chopin, 1987; Dobretsov, 1991) makes it possible to interpret the geodynamic process of UHP rocks in the Dabie Mountain collisional orogen.

\section{Acknowledgements}

This research was supported by Major State Basic Research Development Program of China (G1999075505) and Grants of the Deutsche Forschungsgemeinschaft (OB 80/17). We are grateful to L. Franz for his constructive reviews and suggestions. We also thank G. Martinotti for assistance during field work and beneficial discussions on the earlier manuscript.

\section{References}

Ames, L., Zhou, G., and Xiong, B., 1996, Geochronology and isotopic character of ultrahigh-pressure metamorphism with implications for collision of the Sino-Korean and Yangtze Cratons, central China: Tectonics, v. 15, pp. 472-489.

Anhui Bureau of Geology and Mineral Resources, 2000, Geological map of Changpu area, Yuexi county, Anhui province, scale 1:10000. Anhui People's Publishing House (in Chinese).

Carswell, D. A., Wilson, R. N., and Zhai, M., 2000, Metamorphic evolution, mineral chemistry and thermobarometry of schists and orthogneisses hosting ultra-high pressure eclogites in the Dabieshan of central China: Lithos, v. 52, pp. 121-155.

Chavagnac, V., and Jahn, B-M., 1996, Coesite-bearing eclogites from the Bixiling Complex, Dabie Mountains, China: Sm-Nd ages, geochemical characteristics and tectonic implications: Chemical Geology, v. 133, pp. 29-51.

Chopin, C., 1987, Very-high pressure metamorphism in the Western Alps: Implications for subduction of crust: Philosophical Transaction of the Royal Society of London, Series A, v. 321, pp. 183-197.

Cong, B., 1996, Ultrahigh-pressure Metamorphic Rocks in the DabieshanSulu Region of China: Science Press, Beijing, China, Kluwer Academic Publishers, pp.224.

Cong, B., Wang, Q. and Zhai, M., 1999, New data regarding hotly debated topics concerning UHP metamorphism of the Dabie-Sulu belt, east-central China: International Geology Review, v.41, pp.827-835.

Cong, B., Zhai, M., Carswell, D. A., Wilson, R. N., Wang, Q., Zhao, Z. and Windley, B. F., 1995, Petrogenesis of the Ultrahigh-pressure rocks and their country rocks at Shuanghe in Dabieshan, central China: European Journal of Mineralogy, v.7, pp.119-138.

Davy, P., and Gillet, P., 1986, The stacking of thrust slices in collision zones and its thermal consequences: Tectonics, v. 5, pp. 913-930.

Dobretsov, N. L., 1991, Blueschists and eclogites: A possible plate tectonic mechanism for their emplacement from the upper mantle: Tectonophysics, v. 186, pp. 253-268.

Dong, S., Sun, X., Zhang, Y., Huang, D., Wang, G., Dai, S., and Yu, B., 1993, The basic structure of Dabie collisional orogen: Chinese Sciences Bulletin, v. 38, 1884-1888.

Dong, S., Wang, X., and Huang, D., 1997, Discovery of low grade metamorphic volcanic rock sheets within UHP in Dabie Mts, and its implications: Chinese Sciences Bulletin, v. 42, pp. 1199-1203.

Ellis, D. J., and Green, D. H., 1979, An experimental study of the effect of Ca upon garnet-clinopyroxene Fe-Mg exchange equilibria: Contributions to Mineralogy and Petrology, v. 71, pp. 13-22.

Gao, T., Tang, J., Zhou, C., Hou, M., and Qian, C., 1997, Discovery of eclogite vein in pyroclastic rock of lower greenschist facies in the Dabie Mountains: Chinese Sciences Bulletin, v. 42, pp. 1758-1761 (in Chinese).

Hacker, B. R., Ratschbacher, L., Webb, L. E., and Dong, S., 1995, What brought them up? Exhumation of the Dabie Shan ultrahigh-pressure rocks: Geology, v. 23, pp. 743-746.

Hacker, B. R., Ratschbacher, L., Webb, L. E., Ireland, T., Walker, D., and Dong, S., 1998, Zircon ages constrain the architecture of the ultrahighpressure Qinling-Dabie orogen, China: Earth and Planetary Science Letters, v. 161, pp. 215-230.

Hacker, B. R., Ratschbacher, L., Webb, L. E., McWilliams, M. O., Ireland, T., Calvert, A., Dong, S., Wenk, H-R. ,and Chateigner, D., 2000, Exhumation of ultrahigh-pressure continental crust in east central China: Late Triassic-Early Jurassic tectonic unroofing: Journal of Geophysical Research, v. 105, pp. 13339-13364. 
Hynes, A., and Forest, R. C., 1988, Empirical garnet-muscovite geothermometry in low-grade metapelites, Selwyn Range (Canadian Rockies): Journal of metamorphic Geology, v. 6, pp. 297-309.

Krogh, E. R., 2000, The garnet-clinopyroxene $\mathrm{Fe}^{2+}-\mathrm{Mg}$ geothermometer: an updated calibration: Journal of metamorphic Geology, v. 18, pp. 211-219.

Li, S., Xiao, Y., Liou, D., Chen, Y., Ge, N., Zhang, Z., Sun, S.-S., Cong, B., Zhang, R., Hart, S. R., and Wang, S., 1993, Collision of the North China and Yangtse Blocks and formation of coesite-bearing eclogites: Timing and processes: Chemical Geology, v. 109, pp. 89-111.

Liou, J. G., Zhang, R. Y., Wang, X., Eide, E. A., Ernst, W. G., and Maruyama, S., 1996, Metamorphism and tectonics of high-pressure and ultra-high-pressure belts in the Dabie-Sulu region, China, In Yin, A., and Harrison, M. T., eds, The Tectonic Evolution of Asia: Cambridge University Press, pp.300-344.

Liu, X., Dong, S., Xue, H., and Zhou, J., 1999, Significance of allanite-(Ce) in granitic gneisses from the ultrahigh-pressure metamorphic terrane, Dabie Shan, central China: Mineralogical Magazine, v. 63, pp. 579-586.

Maruyama, S., Tabata, H., Nutman, A. B., Morikawa, T., and Liou J. G., 1998, SHRIMP U-Pb geochronology of ultrahigh-pressure metamorphic rocks of the Dabie Mountains, central China: Continental Dynamics, v. 3, pp. 72-85.

Massonne, H. J., and Schreyer, W., 1987, Phengite barometry based on the limiting assemblage with K-feldspar, phlogopite and quartz: Contributions to Mineralogy and Petrology, v. 96, pp. 212-224.

Oberhänsli, R., Hunziker, J. C., Martinotti, G., and Stern, W. B., 1985, Geochemistry, geochronology and petrology of Monte Mucrone: An example of Eo-alpine eclogitization of Permian granitoids in the Sesia-Lanzo zone, western Alps, Italy: Chemical Geology, v. 52, pp. 165-184.

O'Brien, P., and Treloar, P., 2001, Himalayan Subduction of the Indian plate in NM Pakistan: good, bad and indifferent eye-witnesses. Journal of Conference Abstracts, Cambridge Publications, v. 6, p. 350.

Okay, A. I., 1993, Petrology of a diamond and coesite-bearing metamorphic terrain: Dabie Shan, China: European Journal of Mineralogy, v. 5, pp. 659-673.

Okay, A. I., Xu, S., and Sengor, A. M. C., 1989, Coesite from the Dabie Shan eclogites, central China: European Journal of Mineralogy, v. 1, pp. 595598.

Platt, J. P., 1986, Dynamics of orogenic wedges and the uplift of high-pressure metamorphic rocks: Geological Society of American Bulletin, v. 97, pp. 1037-1053.

Rowley, D. B., Xue, F., Tucker, R. D., Peng, Z. X., Baker, J., and Davis, A., 1997, Ages of ultrahigh pressure metamorphism and protolith orthogneisses from the eastern Dabie Shan: U/Pb zircon geochronology: Earth Planetary Science Letters, v. 151, pp. 191-203.

Schmid, R., Oberhänsli, R., Martinotti, G., Franz, L., Liu, X., and Dong, S., 2000, Basement-cover sequences within the UHP unit of the Dabie Shan, E-China: European Journal of Mineralogy, v. 12, Beiheft 1, p.183.

Schmid, R., 2001, Geology of Ultrahigh-Pressure Rocks from the Dabie Shan, Eastern China. Ph.D. thesis, Institut für Geowissenschaften, Universität Potsdam, p.141.

Schmid, R., Franz, L., Oberhänsli, R., Romer, R., Martinotti, G., Liu, X., and Dong, S., 2001, A continental rift in UHP-facies: the Dabie Shan: Journal of Conference Abstracts, Cambridge Publications, v. 6, p.348.

Su, W., Xu, S., Jiang, L., and Liu, Y., 1996, Coesite from quartz jadeitite in the Dabie Mountains, eastern China: Mineralogical Magazine, v. 60, pp. 659-662.

Tabata, H., Yamauchi, Y., Maruyama, S., and Liou, J. G., 1998, Tracing the extent of a UHP metamorphic terrane: Mineral-inclusion study of zircons in gneisses from the Dabie Shan, In Hacker, B. R., and Liou, J. G., eds,
When Continents Collide: Geodynamics and Geochemistry of UltrahighPressure Rocks: Kluwer Academic Publishers, pp. 261-273.

Tang, J., Qian, C., and Gao, T., 1995, Discovery of low-grade metamorphic volcanic-detrital rock association in eclogite belt in the Dabie Mountains and its geological significance: Geology of Anhui, v. 5, pp. 29-35 (in Chinese with English abstract).

Wang, X., and Liou, J. G., 1991, Regional ultrahigh-pressure coesite-bearing eclogitic terrane in central China: Evidence from country rocks, gneiss, marble, and metapelite: Geology, v. 19, pp. 933-936.

Wang, X., and Liou, J. G., 1993, Ultra-high-pressure metamorphism of carbonate rocks in the Dabie Mountains, central China: Journal of metamorphic Geology, v. 11, pp. 575-588.

Wang, X., Liou, J. G., and Mao, H. K., 1989, Coesite-bearing eclogites from the Dabie Mountains in central China: Geology, v. 17, pp. 1085-1088.

Webb, L. E., Hacker, B. R., Ratschbacher, L., McWilliams, M. O., and Dong, S., $1999,{ }^{40} \mathrm{Ar} /{ }^{39} \mathrm{Ar}$ thermochronologic constraints on deformation and cooling history of high and ultrahigh-pressure rocks in the Qinling-Dabie orogen: Tectonics, v. 18, pp. 621-638.

$\mathrm{Xu}, \mathrm{Z} ., 1987$, Etude tectonique et microtectonique de la chaine paleozoique et triasique des Qinlings (Chine): Presente a L'Universite des Sciences et Techniques du Languedoc Pour obtenir le diplome de Doctorat, pp. 93107.

Xue, F., Rowley, D. B., and Baker, J., 1996, Refolded syn-ultrahigh-pressure thrust sheets in the south Dabie complex, China: Field evidence and tectonic implications: Geology, v. 24, pp. 455-458.

Zhai, M., Cong, B., Zhao, Z., Wang, Q., Wang, G., and Jiang, L., 1995, Petrological-tectonic units in the coesite-bearing metamorphic terrain of the Dabie Mountains, central China and their geotectonic implications: Journal of Southeast Asian Earth Sciences, v. 11, pp. 1-13.

Zhang, R. Y., and Liou, J. G., 1997, Partial transformation of gabbro to coesite-bearing eclogite from Yangkou, the Sulu terrane, eastern China: Journal of Metamorphic Geology, v. 15, pp. 183-202.

Zhao, Y., Liu, X., Song, B., Zhang, Z., Li, J., Yao, Y., and Wang, Y., 1995, Constraints on the stratigraphic age of metasedimentary rocks from the Larsemann Hills, East Antarctica: possible implications for Neoproterozoic tectonics: Precambrian Research, v. 75, pp. 175-188.

Dong Shuwen has been professor at Chinese Academy of Geological Sciences (CAGS) since 1994. He was awarded B.S. in geology from Tech-University of Hefei in 1975, M.S. in structural geology from CAGS in 1981, and doctorate in tectonic and geomechanics from $C A G S$ in 1988. His present research is focused on tectonics of collisional belt, and deformation and exhumation of HP-UHP metamorphic rocks in the Dabie Mountain orogen, east China.

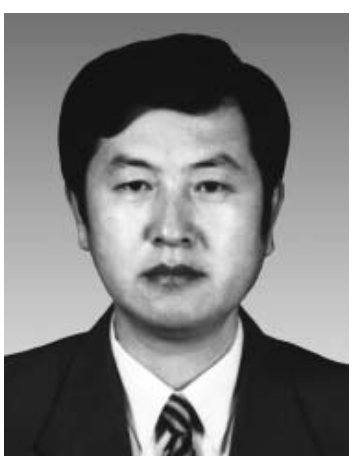

